To cite this article: David Oguche \& Asabe Aliyu (2020) Towards a National Framework for Digital Preservation in Nigeria: Technologies and Best Practices. Information Impact: Journal of Information and Knowledge Management, 11:4, 146-155, DOI: https://dx.doi.org/10.4314/iiijkm.v11i4.14

To link to this article: https://dx.doi.org/10.4314/iijikm.v11i4.14

\title{
Towards a National Framework for Digital Preservation in Nigeria: Technologies and Best Practices
}

\author{
${ }^{1}$ David Oguche \\ ${ }^{2}$ Asabe Aliyu
}

\begin{abstract}
The need for preserving digital resources (acquired or generated) by institutions in Nigeria becomes imperative in the wake of adoption of Information and Communication Technologies (ICT) by these institutions. The paper advocates for a national framework for preserving digital resources for longterm or future use and to avoid the risk of losing national memory in this digital age. Technology emulation, migration and encapsulation are some of the digital preservation strategies discussed in the paper. The paper also identified two key national institutions that can drive the digital preservation initiative in Nigeria.
\end{abstract}

Keywords Archive, Preservation, Digital materials, Technology Obsolence

CONTACT David Oguche and Asabe Aliyu ogucheed@gmail.com Nigerian Institute for Advanced Legal Studies, FCT, Abuja and Sa'adatu Rimi College of Education Kumbotso, Kano 


\section{Introduction}

The implementation of Nigerian National Policy for Information Technology as well as the National Policy on Telecommunication has resulted in enormous amounts of digital objects creation in Nigeria. This culminated in an exponential growth in the amount of digital material created or generated by individuals, government, institutions and corporate entities over the years .It has also generated a high demand for computers in all end-user segments in the country which consequently led to high internet usage in the country. There are over 91 million internet users in Nigeria (Internet World Statistics, 2018). Government agencies and departments in Nigeria are adopting ICTs for their operations, the business sectors have embraced the use of computers and Internet services in their operations, the Nigerian scholarly and research communities are also not left out in the production of digital objects. Gbaje (2011) observed that researchers and scholars of universities, polytechnics, colleges and research institutions produce enormous amount of data and research output in form of publications, which for the past few years are in digital formats. The foregoing clearly reveals that substantial amount of information from the various sectors of the society is in digital format, hence the need to preserve them for future re-use.

Digital preservation experts have noted that investment in the creation of digital materials is threatened by the rapid change in computer software and hardware technologies hence, the number of ways in which digital materials can be stored is also increasing, resulting in large quantity of digital materials containing vital personal, corporate and societal information, in an ever expanding number of file formats. There is need therefore, to preserve these digital resources for long term or future use to avoid the risk of losing our collective memory in this digital age because electronic information can be easily lost through neglect or lack of awareness of the need to take active steps to ensure its preservation.

\section{Digital Preservation}

Preservation is an umbrella term under which most librarians and archivists cluster all the policies and options for action, including conservation treatments of different formats of information materials (Kalusopa \& Zulu, 2009). The purpose of preservation is to ensure the protection of information of enduring value for access by present and future generations. Libraries and archives have served as the central institutional focus for preservation, and both types of institutions include preservation as one of their core functions. Recently, major libraries especially academic and research libraries and archives in Nigeria have established formal digitisation programs as part of preserving their collections, and have also incorporated digital preservation needs and requirements into overall program planning.

Digitization has become one of the standard forms of preservation for libraries, archives and information centers. This process (digitisation) is allowing preservationists to ensure information contained within fragile, organic materials will still be viewable to future generations. According to Pery (2014), as technology changes, there are concerns that the methods used today to preserve these materials are not going to be sufficient or even viable in the future because software and formats change very quickly, and could be obsolete in a relatively short time period. This applies both to hard copy materials that are converted into digital copies, as well as born-digital items, or those who were created as digital copy initially. For this reason, digitization is not strictly a preservation activity, as the new files will require preservation as well.

Conway (2010) gave a clear distinction between the terms "digitization for preservation" and "digital preservation." Digitization for preservation creates valuable new digital products, whereas digital preservation protects the value of those products, regardless of whether the original source is a tangible artefact or data that were born and live digitally. Digitization for preservation and digital 
preservation are intimately related, but the underlying standards, processes, technologies, costs, and organizational challenges are quite distinct. The recognition of digitization as a preservation strategy is a relatively new concept within the cultural heritage community, which has generally viewed digitization activities as a form of copying for easier and broader access. Digital material preservation is a way of preserving information materials which refers to digital surrogates created as a result of converting analogue materials to digital form (digitisation) and those that are "born digital" for which there has never been and is never intended to be an analogue equivalent, and digital records (Kalusopa \& Zulu, 2009). The phrase "digital preservation" embraces two major categories based on the principle of how or the process by which digital materials came into existence or rather were created (Digital Preservation Coalition, 2002). Thus, "born digital" refers to materials which were not intended to have an analogue equivalent, either as the originating source as a result of conversion to analogue form. Similarly, the phrase "made digital" refers to creating digital files by scanning or otherwise converting analogue materials and the resulting digital copy are classed as a digital material.

The Joint Information Systems Committee (2012) defined digital preservation as the series of actions and interventions required to ensure continued and reliable access to authentic digital materials for as long as they are deemed to be of value. In general, digital preservation involves a number of organised tasks associated with a variety of technical approaches, or strategies for ensuring that digital resources are not only stored appropriately, but are also adequately maintained and thus consistently useable over time. According to Webb (2003), preserving digital materials is achieved by finding ways to re-present what was originally presented to users through a combination of computer software and hardware. It requires digital materials to be understood and managed at four levels as:

- Physical phenomena

- Logical encodings

- Conceptual objects that have meaning to humans and

- Assets of essential elements that must be preserved in order to offer future users the essence of each object.

Hedstrom (1995) noted that there are two perspectives for examining digital preservation requirements viz-a-viz; from the perspective of users of digital materials and from the view of libraries, archives, and other custodians who assume responsibility for their maintenance, preservation and distribution. The most basic requirements from a user point of view include the ability to establish the authenticity and integrity of a source, document structures, metadata that document the maintenance and use history of the document, time and date stamps, and a series of references.(Matthews etal., 1997). Rothenberg (1995) summarised that though digital preservation requirements may be defined differently by archives, libraries, and other types of repositories, all these institutions, need storage systems capable of handling digital information. The terms digital preservation and digital archiving are often thought to be synonymous and therefore used interchangeably. However, there is a fundamental difference between the two. While digital preservation refers to a series of adopted management activities necessary to ensure a continued access to digital materials for as long as necessary, digital archiving is referred to as the process of creating backup as an on-going maintenance as opposed to strategies for long-term digital preservation (DPC, 2002).

\section{Approaches to Digital Preservation}

Digital preservation strategies are methods for keeping stored digital objects permanently accessible for long-term re-use. Implementing a digital preservation strategy is a crucial part of managing the 
risk associated with rapid hardware and software obsolescence. Strategy is a general framework that provides guidance for actions to be taken and, which at the same time, is shaped by the actions being taken. To preserve the Digital assets, there are some approaches to access the preserved contents in future. According to Ippolito (2010), there are four principal preservation options: traditional "storage," which is least effective for new media because of the need to upgrade hardware and software; "emulation," which is re-creating the work on new software or equipment to retain its original appearance and "migration," or continual upgrading from one medium to another for example, from video disc to DVD as technology progresses. The last method is "reinterpretation," which is akin to restaging a performance piece. The Approaches to Digital preservation can be elucidated in a five different approaches as follows:

Technology Preservation:

Technology preservation is the short- term solution of digital preservation problem. In this approach the content can preserve in the exact technology in which it was appeared. The advocates of this strategy emphasize that the original environment needs to be run to really preserve the behaviour as well as the look and feel of the digital object. For some digital objects, this may be the best solution at least in the short-term because it ensures that the material is accessible by preserving the access tools as well as the object itself. Hendly (1998) posited that technology preservation is an attempt to ensure the usability of digital resources over time by preserving and maintaining software(applications and operating systems) hardware, essentially creating an IT museum. The main issue of relevance in technology preservation strategy is that information and communication technologies (ICT) evolve over time and digital information may become inaccessible through technological obsolescence. Preserving the technology required to access digital information is really only a short-term strategy. Thibodeau (2002) opined that technology preservation is not a viable strategy for long-term digital preservation, for the following reasons:

a) The cost and space implications for acquiring and maintaining large quantities of hardware (from computers and peripherals to connectors) are prohibitive for many organizations.

b) Older operating system and application software and appropriate licenses must also be acquired and maintained.

c) After some time, the machines will degrade and ultimately fail, so the number of machines capable of reading certain types of old files will continually decrease.

d) Technical support for both software and hardware will also disappear over time.

e) Documentation for older computing environments can be difficult to locate.

Technology Emulation

Emulation is the process to preserve the copy of original digital objects or application software for next generation use. This strategy does not involve preserving ageing hardware and original operating system software. The goal of emulation is to preserve the look and feel of the digital object as well as its functionality. The essence of this strategy according to Lee (2002) and Granger (2000) is to copy the technical context of the resource allowing the original object or a refreshed copy of the original object to be used in the future. Emulation refers to the process of mimicking, in software, a piece of hardware or software so that other processes think the original equipment/function is still available in its original form. Emulation is essentially a way of preserving the functionality of and access to digital information which might otherwise be lost due to technological obsolescence (National Library of Australia, 2010). Instead of endlessly transferring files from one format to another like proposed in migration, emulation focuses on developing system that mimic the application software used to create the original document. 


\section{Information Migration:}

Migration or Conversion is the same terms which are used as digital preservation technology. Its aim is to preserve the actuality of the digital objects with the latest technologies and provide the right of entry to user to regain, show and use it. Digital migration is broadly described as moving into the new or advanced digital standard without compromising the realities of the current standard. In the words of Kataria and Anbu (2010) Migration is most commonly used preservation strategy, especially for non-interactive digital objects such as images, databases or textual documents. Before any digital object is migrated, two important decisions must be made, format and application; the target format and the application software for migration. The purpose of migration is to preserve the integrity of digital objects and to retain the ability of users to retrieve, display, and use them in the face of constantly changing technology. The migration of digital information refers to the periodic transfer of digital materials from one hardware/software configuration to another, or from one generation of computer technology to a subsequent generation.

\section{Technology Encapsulation}

Encapsulation is the process which is basically a way to assemble jointly all the applicable material for the digital object and to manage the resulting digital object as one. Encapsulation aims to overcome the problems of the technological obsolescence of file formats by making the details of how to interpret the digital object part of the encapsulated information. This strategy involves creating the original application that was used to create or access the digital object on future computer platforms. Part of the process of encapsulation may be to migrate the entire record to a more easily documented format. Encapsulation in the context of preserving digital materials is a technique of grouping together a digital object and anything else necessary to provide access to that object. Encapsulation can be achieved by using physical or logical structures called "containers" or "wrappers" to provide a relationship between all information components, such as the digital object and other supporting information such as a persistent identifier, metadata, software specifications for emulation. Encapsulation has been widely promoted by Rothenberg who is a strong advocate of encapsulation and emulation methods for digital preservation

\section{Reinterpretation}

This is the approach in which a particular definition or formula or coding is reinterpreted with new words. Reinterpretation allows preservation professionals to make decisions about the characteristics of an objects presentation or performance within some pre-defined boundaries. Currently, artist questionnaires are the primary means of developing a representation of a variable media artwork with an eye towards reinterpretation (Winget, 2005). Re-interpretation, which basically allows museum and archives professionals to make decisions about the characteristics of a variable media object's presentation or performance within some pre-defined boundaries.

These different approaches are suitable for different data-types and for different working environment depending on the nature of digital documents which include cost, expertise, software and technical requirements.

\section{Global Initiatives on Digital Material Preservation}

International organizations and institutions have been in the forefront of promoting digital preservation of materials of national heritage. This has led to the success of so many initiatives and projects some of which are already in place while others are still underway. Kalusopa and Zulu (2009) reported that UNESCO has been at the forefront of universal efforts in digital preservation initiating universal strategies to be adopted to preserve digital material. Others include the International Federation of Library Associations (IFLA), the Joint Information Systems Committee (JISC) and the Digital Preservation Coalition (DPC). UNESCO's drive has led to proclamation of a Charter on the 
Preservation of the Digital Heritage. The Charter which is a declaration of principles to assist UN Member States in preparation of national policies to preserve and provide access to digital heritage, describes the digital heritage as those unique resources of human knowledge and expression in digital form, and recognizes both the risk to this material through technological obsolescence and the urgency required to ensure its preservation (Lusenet, 2007). According to UNESCO report (2003), follow-up meetings and activities to the Charter was held in the Caribbean in 2005 focusing on preservation of audio-visuals and the Ethiopia workshop in August, 2006 was devoted to "develop regional action plans and strengthen co-operation".

IFLA is another major player involved in the global initiatives on digital preservation. According to Kalusopo and Zulu (2009), IFLA guidelines on digitisation were produced by a working group representing IFLA and the International Council of Archives (ICA).Other universal efforts have been made by the DPC which was established in 2001 to foster joint action to address the urgent challenges of securing the preservation of digital resources in the UK and to work with others internationally to secure global digital memory and knowledge base. Its aim, since its launch, has been to raise the profile of digital preservation on behalf of all its members, which it has pursued through work with international bodies such as UNESCO and the European Commission. DPC has also managed to have a joint service of the DPC and Preserving Access to Digital Information (PADI) which is in the form of a quarterly summary publication of selected recent activity in the field of digital preservation compiled from the PADI gateway, the digital preservation and mailing lists and other sources. The goal of the above universal initiatives, as summarized by UNESCO, has been "to maintain access to digital resources over a long term by safeguarding not necessarily the storage media but the content and documentation and thus taking care of the aspect of information integrity at large" The status of digital preservation in Africa is worth mentioning. Studies from available literature shows that developed nations have done well in digital material preservation programs. This is corroborated by Tsebe (2005) when he stated that while several developed countries such as New Zealand, Australia, the UK and the U.SA have taken national digital material preservation initiatives over the years, most African countries have been grappling with identifying strategies that they can use to deal with digital preservation issues. Although very few countries initiated national preservation projects but these projects were sponsored and taken over by foreign bodies. For instance, the National Library of South Africa was tasked by IFLA in its project "Networking Cultural Heritage". The project was to investigate digitisation activities at national libraries and to encourage cooperation amongst heritage institutions (libraries, archives and museums) at either the national or the international level (Tsebe, 2005).

Other efforts in Africa include; the African World Heritage Fund (AWHF) which was setup by UNESCO in 2006 to effect the conservation and protection of Africa's natural and cultural heritage, The Centre for Heritage Development in Africa (CHDA) established in 2000 as the Programme for Museum Development in Africa as well as the International Federation of Library Associations and Institutions (IFLA) Preservation and Conservation Centres (PACs) created to coordinate worldwide cooperation for the preservation of library materials. (Kalusopa \& Zulu, 2009)

\section{Overview of Key Heritage Institutions in Nigeria}

\section{National Library of Nigeria}

According to Laws of the Federation of Nigeria (LFN, 2004), The National Library of Nigeria was established by the National Library Act 1964 which was later repealed and substituted with the National Library Act No. 29 of 1970. The mission of National Library of Nigeria is to acquire process, organize, disseminate as well as provide links to information resources to all Nigerians and 
non-Nigerians for their educational pursuits and for informed decision making. Some of the functions of the National Library according to the status establishing it, amongst others, include:

i. Assembling, maintaining and extending a collection of books, periodicals, pamphlets, newspapers, maps, musical scores, films and recordings and related information sources which the Board considers appropriate for a library of the highest standing.

ii. To collect legal deposit materials, in order to facilitate the distribution of published materials.

iii. To make the facilities of the National Library available to members of the public and others on proper terms.

iv. To be responsible for the development of the National Bibliography of Nigeria and national bibliographical services, either in a national bibliographical centre or elsewhere.

v. To ensure adequate documentation and dissemination of Nigerian Indigenous literatures.

\section{The National Archives of Nigeria}

The National Archives of Nigeria is the repository of the non-current/current records of the Government of Nigeria, within it holds in trust for the use of administrators, scholars and general public. It is an attached office of the Department of National Archives under the Federal Ministry of Information and Communications. The Nigerian Record Office was placed under the administrative control of the Public Works Department until it was transferred to the Ministry of Education in 1957. On the 14th of November 1957, the Public Archives Ordinance No. 43 was passed, and it authorized the establishment of the National Archives of Nigeria to provide for the preservation of public archives. The Act empowered the National Archives of Nigeria to establish as many branches as might be deemed necessary and convenient. The 1957 Archives Ordinance has since been repealed by the promulgation of the National Archives Decree no. 30 of July 8th 1992. By the promulgation of the Decree, the inadequacies observed in the Archives Ordinance were rectified. The Decree requires that National Archive preserve under adequate security conditions, all original constitutional instruments, treaties, law, decrees and other legal enactments of the Federal Government.

The policy thrust of the Department of National Archives of Nigeria is enshrined in its current enabling law - National Archives Act of 1992, which entrusts National Archives of Nigeria with the permanent custody, care and control of all archives of the Federal Government and of such other archives and historical records as may be required, from time to time pursuant to the Act. As the apex archival institution in Nigeria the Act further provides for the management and preservation of public records, records of individuals, private bodies and companies. Records acquired and preserved by the National Archive include the followings:

i. Federal Government gazettes

ii. Proceedings and laws promulgated by the National Assembly

iii. Reports of various administrative and Judicial commission on enquires

iv. Federal Executive Council conclusions

v. Non-current records from Federal Ministries of interior, labour, environment, Customs Services, etc

vi. Publications from ministries, departments and agencies

vii. Photographs of some public officers.

\section{Preliminary Steps towards establishing a viable Digital Preservation project in Nigeria}

Evidences from available literature and preliminary investigation in the course of this research revealed that some important building blocks for the formulation of a viable national digital preservation program do exist. For instance, the decree establishing the National library of Nigeria, 
stipulates that fifteen copies of all Nigerian material of high national significance should be deposited at the National Library, while the National Archive also has the mandate by law to collect and preserve government records. However, there is no clear provision within these laws for the collection and preservation of digital materials. The following steps can guide the nation to a ready stage for National Digital Preservation programme:

\section{Review of the National Library and National Archive's Acts}

To achieve a successful digital preservation program in Nigeria, the National Library Act No. 29 of 1970 and the National Archives Act of 1992 should be reviewed to accommodate preservation of digital materials. Although the virtual library department of National Library of Nigeria has been saddled with digitization and preservation of electronic national heritage materials in the library's possession, this however, is not sufficient for a national digital preservation project considering the allocated budget.

\section{Establishment of a National Digital Preservation Program}

Successful digital preservation program would rely adequately on legislation among others. A new legislation establishing National Digital Preservation project (NDPP) should be enacted. The legislation should mandate National Library of Nigeria and the National Archive to lead a national planning effort for the long-term preservation of digital content, and to work collaboratively with representatives of other federal agencies, research, library, and business organizations. Most of the successful NDPP around the world have adopted this option for example National Digital Information Infrastructure and Preservation Program (NDIIPP) of America, Deposit of Netherlands Electronic Publications (DNEP), and Preserving and Accessing Networked Documentary Resources of Australia (PANDORA)

\section{Implementing a Digital Preservation Policy}

A key element of any digital preservation is the policy. A policy statement would set clear priorities, and a national digital preservation policy would reinforce mutual efforts of government to preserve materials that document the nation's cultural heritage. It would define organizational roles and (funding) responsibilities. The roles of established memory institutions, such as libraries, archives, museums, and other stakeholders would also be addressed. The model framework and guidance for the development of digital preservation policy and implementation clauses as indicated in table 1 below can be taken into consideration when drafting digital preservation policy.

Table 1: The Model Digital Preservation Policy and Implementation Clauses.

\begin{tabular}{|l|l|}
\hline Clause & Description \\
\hline Principle Statement & $\begin{array}{l}\text { Addresses how the digital preservation policy can serve the needs of the } \\
\text { organization and the benefits its well-being. }\end{array}$ \\
\hline Contextual Links & $\begin{array}{l}\text { Highlights how this policy integrates into the organization and how it relates } \\
\text { to other high level strategies and policies }\end{array}$ \\
\hline Preservation Objectives & $\begin{array}{l}\text { Provide Information about the preservation objectives and how they will be } \\
\text { supported }\end{array}$ \\
\hline Identification of Content & $\begin{array}{l}\text { Outlines what the policy's overall scope is in terms of content and its } \\
\text { relationship to collection development aims. }\end{array}$ \\
\hline Procedural Accountability & $\begin{array}{l}\text { Identifies high level responsibilities for the policy and provide recognition of } \\
\text { the most important obligations faced in preserving key institutional } \\
\text { resources. }\end{array}$ \\
\hline Guidance and Implementation & $\begin{array}{l}\text { Guidance and implementation clauses on how to implement the } \\
\text { preservation policy and/or identification of where additional guidance and } \\
\text { procedures are available in separate documentation or from staff. }\end{array}$ \\
\hline
\end{tabular}




\begin{tabular}{|c|c|}
\hline & Implementation Clauses \\
\hline Financial and Staff Responsibility & $\begin{array}{l}\text { This section should be about who is responsible for digital preservation } \\
\text { within the organization. It should also be about financial sustainability and } \\
\text { how the policy sits within the organizational financial plan. }\end{array}$ \\
\hline Intellectual Property & $\begin{array}{l}\text { This clause shows awareness of copyright issues and how the institution } \\
\text { plans to recognize and tackle these key issues. }\end{array}$ \\
\hline Distributed Services & $\begin{array}{l}\text { In some situations it may be more convenient or cost- effective to outsource } \\
\text { some or all preservation activities. }\end{array}$ \\
\hline Standards Compliance & Lists here what standards the archive is committed to. \\
\hline Review and Certification & $\begin{array}{l}\text { A description of how often a review of the policy is carried out, for example, } \\
\text { bi-annually, yearly, biennially. }\end{array}$ \\
\hline Auditing and Risk Assessment & $\begin{array}{l}\text { Procedures for carrying out standardized auditing and recognition of risks } \\
\text { facing the policy. }\end{array}$ \\
\hline Stakeholders & $\begin{array}{l}\text { Identification of all parties involved in the policy and its implementation } \\
\text { procedures. }\end{array}$ \\
\hline Preservation Strategies & $\begin{array}{l}\text { A guidance table on preservation strategies adopted and technical } \\
\text { implementation of the policy. }\end{array}$ \\
\hline Glossary & List of definitions, if required. \\
\hline
\end{tabular}

Source: Charles Beagriet. al.

$<$ http://citeseerx.ist.psu.edu/viewdoc/download?doi=10.1.1.214.9056\&rep=rep1\&type=pdf>

\section{Conclusion}

In the digital preservation journey, an important question which arises is why we need to preserve the digital assets. The answer to this question is obvious; to preserve memories. Also, there will be no use of inventions, researches and discoveries if they will not be preserved appropriately for the upcoming generation. Digital Preservation has become increasingly important component in this digital information age. It is the mechanism for the prevention of our digital memory and digital heritage. A viable digital preservation program in Nigeria will go a long way in creating digital fortress where digital information is safely stored for the current and future generations.

\section{References}

Conway, P. (2010) Preservation in the Age of Google: Digitization, Digital Preservation, and Dilemmas. 80(1) The Library Quarterly 7 <http://www.jstor.org/stable/10.1086/648463> Accessed 9 March, 2019

Digital Preservation Coalition (DPC) (2002), "DPC history", available at www.dpconline.org/graphics/about/history.html (accessed 10 October 2005).

Digital Preservation Coalition (DPC) (2005), "DPC/PADI What's new in digital preservation", available at: www.dpconline.org/graphics/whatsnew/ (accessed 7 October 2020).

Gbaje, E. (2011) Digital Preservation Policy and Implementation Strategies for National Information Centres in Nigeria a dissertation submitted in partial fulfillment of the requirements for the degree of doctor of philosophy in information science, Department of Library and Information Science Ahmadu Bello University, Zaria

Hendly, T. (1998) "comparison of methods and costs of digital preservation" British library research and innovation report. 106.

Hedstrom, M. (2003)It's about Time: Research Challenges in Digital Archiving and Long-Term Preservation.Washington, DC: Library of Congress and National Science Foundation. 
Hedstrom, M. (1995), "Electronic archives: integrity and access in the network environment", in Stephanie, K. and Seamus, R. (Eds), Proceedings of the Second Conference on Scholarship and Technology in the Humanities, Elvetham Hall, Hampshire, UK, 13-16 April, pp. 77-95.

Internet World Statistics (2018) Nigeria Internet usage Reports http://www.internetworldstats.com/af/ng.htm

Joint Information Systems Committee.(2006) 'Digital preservation briefing paper' <www.jisc.ac.uk/publications/documents/pub_digipreservationbp.aspx> Accessed 22 March, 2017

Kalusopa, T. and Zulu, S. (2009),"Digital heritage material preservation in Botswana: problems and prospects", Collection Building, Vol. 28 Iss 3 pp. 98 - 107

Kataria, S. and AnbuJ . (2010) "How safe is our digital tomorrow? Role of libraries and information centers in digital preservation" Proceedings of ICSIT 2010

Lee, K. (2002) "The state of the art and practice in digital preservation." Journal of Research of the National Institute of Standards and Technology vol. 107, no.1,

Lusenet, Y. (2007), "Tending the garden or harvesting the fields: digital preservation and the UNESCO charter on the preservation of the digital heritage", Library Trends, Vol. 56 No. 1, pp. $164-82$.

Matthews, G., Poulter, A. and Blagg, E. (1997), Preservation of Digital Materials Policy and Strategy Issues for the UK: Report of a Meeting Held at the British Library Research and Innovation Centre, London, 13 December 1996, British Library Research and Innovation Centre, London.

National Archive Act 1992. Also available at:<http://lawnigeria.com/LawsoftheFederation/NATIONAL-ARCHIVES-ACT.html>

National Library Act No. 29 1970. Also available at:<http://lawnigeria.com/LawsoftheFederation/NATIONAL-LIBRARY-ACT.html>

PADI, National Library of Australia, Retrieved on June 30, 2019 from http://www.nla.gov.au/padi/topics/17.html

Rothenberg, J. (1995), "Ensuring the longevity of digital documents", Scientific American, Vol. 272, January, pp. 42-7.

Thibodeau K. (2002) Overview of Technological Approaches to Digital Preservation and Challenges in Coming Years Digital Preservation: An International Perspective. Conference Proceedings. Retrieved on 12/09/2009, from http://www.clir.org/PUBS/reports/pub107/pub107.pdf

Tsebe, J. (2005) 'Networking cultural heritage: Africa'

UNESCO (2003) 'Guidelines for the preservation of digital heritage', 27 $<$ http://unesdoc.unesco.org/images/0013/001300/130071e.pdf> Accessed 10 November 2019

UNESCO 'DPC/PADI: What's new in digital preservation (3003) available at $:<$ www.unesco.org > Accessed 29 March 2017

<www.ifla.org/IV/ifla71/papers/157e-Tsebe.pdf> Accessed 19 February 2019

UNESCO (2003a) Vol. 27, "Guidelines for the preservation of digital heritage", available at: http://unesdoc.unesco.org/images/0013/001300/130071e.pdf (accessed 27 September 2019).

UNESCO (2003b), "UNESCO Charter on the preservation of the digital heritage: Document 32

C/28", available at: http://portal.unesco.org/en/ev.php (accessed 6 October 2020).

UNESCO (2003c), "DPC/PADI: What's new in digital preservation”, available at: www.unesco.org (accessed 29 September 2020).

Webb, C. (2003) Guidelines for the preservation of digital heritage available at: <http://unesdoc.unesco.org/images/0013/001300/130071e.pdf> Accessed 11 April 2020

Winget, M. (2005) "Digital Preservation of New media art through exploration of established symbolic representation systems." ACM/IEEE Joint conference on Digital Libraries Doctoral Consortium. Denver, Colorado, June 7-11, 2000 